\title{
Reproductive Performance and Reconception of Nellore Cows According to Their Pure- or Cross-Bred Calves
}

\author{
WB Rodrigues ${ }^{1}$, FS Wechsler ${ }^{1}$ and E Nogueira ${ }^{2}$ \\ ${ }^{1}$ Department of Animal Production, UNESP, Botucatu, SP, Brazil, ${ }^{2}$ Brazilian Agricultural Research Corporation, EMBRAPA Pantanal, Corumbá, \\ MS, Brazil
}

\begin{abstract}
Contents
The objective of the present research was to evaluate the effect of a calf's genetic group on the productive and reproductive efficiency of its Nellore dam. Fixed-time artificial insemination was applied to 800 cows using semen extracted from Nellore, Simmental and Angus Red bulls. Four hundred eleven cows calved, producing 119 Nellore, 103 1/2Simmental-1/2Nellore and 189 1/2Nellore $-1 / 2$ Angus Red calves. The second mating period, which paired Nellore cows with Simmental bulls, was initiated 10 days after parturitions began and lasted for 5 months. Based on the two successive parturitions, the cumulative parturition rate for calving periods of 3,4 and 5 months was calculated. Although no significant difference was observed for birth weight among the genetic groups, cross-bred calves weighed, on average, $10 \%$ more than did pure-bred calves at the age of 205 days. Nellore dams experienced a gestation period that was 7 days longer than did the cross-bred dams, and the former showed a higher parturition rate at 90 and 120 days of the calving season, but not at 150 days (calving rates of $80.6,76.4$ and $76.2 \%$ for mothers of Nellore, $1 / 2$ Nellore $-1 / 2$ Angus Red and $1 / 2$ Nellore- $1 / 2$ Simmental, respectively, $\mathrm{p}>0.05$ ). At 90 and 120 days, Nellore dams produced more $\mathrm{kg}$ of calf per mated dam. In conclusion, in a short breeding season, Nellore dams nursing pure-bred Nellore calves were found to have a higher biological efficiency compared with Nellore dams nursing cross-bred calves.
\end{abstract}

\section{Introduction}

The cross-breeding of cattle has become an important tool for increasing beef production under the different systems used in Brazil. The combination of selection and crosses allows breeders to obtain animals that are efficient in various environments and conditions to meet the demands of the consumer market with flexibility. The total production rates may be increased by $10-20 \%$ in crosses between Bos taurus breeds in favourable environmental conditions by and $30-50 \%$ in crosses between B. taurus and Bos indicus breeds under unfavourable environmental conditions (Koger 1980; Teixeira and Albuquerque 2003).

The Nellore is the most common breed of beef cattle in Brazil because of its ability to adapt to a wide range of local and regional environments. However, many authors agree that cross-breeding may improve the production rates of the herds (Euclides Filho et al. 2003): in Nellore cows, the calving interval (CI) is quite variable, ranging from 358.7 days, which is close to the recommended $12-13$ months, to 459.6 days. The optimal duration of the period of service (PS) is 60 90 days, considering the annual production target of one calf per cow. Yet, cattle raised in tropical regions have an excessively long PS. Environmental factors related to nutritional management have the largest impact on Nellore reproduction. In general, the dietary energy levels both before and after birth are responsible for triggering the resumption of ovarian activity after calving (Wiltbank et al. 1962). Long periods of postpartum anoestros are often observed in cows that experience nutritional deficiencies during the late pregnancy and early lactation phases (Short et al. 1990; Montiel and Ahuja 2005).

In cows with no nutritional deficiencies, the frequency, intensity and duration of suckling are primarily responsible for post-partum anoestros. Frequent calf suckling induces neurohormonal stimuli that trigger the release of $\mathrm{GnRH}$ from the hypothalamus, resulting in lower LH concentrations and the subsequent suppression of ovulation (Williams 1990; Flores et al. 2007).

When crosses are induced to obtain a better performance of a superior calf, the negative effect incurred in the cow is frequently overlooked. For example, studies have shown that Hereford heifers that birthed calves fathered by Angus Red or Simmental bulls subsequently experienced lower rates of pregnancy than did the mothers of pure-bred Hereford calves (Doornbos et al. 1986), whereas B. indicus (Zebu) cows lactating crossbred calves experienced a significant increase in service period, leading to a loss of reproductive efficiency (Paschal et al. 1991; Browning et al. 1996).

The goal of this study was to examine whether the productive and reproductive performance of Nellore cows are influenced by the genotype of their calves over the course of a restricted breeding season.

\section{Materials and Methods}

The experiment was conducted on a commercial farm located in Mato Grosso do Sul, in Brazil. Cattle were kept in several paddocks $30-40$ ha in size on pastureland dominated by Brachiaria brizantha grass under a continuous rotational system, with an average of 11.5 AU/ha/year. A mineral mixture was provided ad libitum throughout the year.

Fixed-time artificial insemination was applied to 800 multiparous Nellore females approximately 40 days 
post-partum, following a protocol of vaginal progesterone implants in combination with applications of oestradiol benzoate, prostaglandin and eCG, during the months of December 2006 (245 females) and January 2007 (155 females), February 2007 (140 females), and March 2007 (260 females). Semen was extracted from two Angus Red, two Simmental and three Nellore bulls and assigned to the Nellore cows at random. After each collection, semen was evaluated to confirm uniform sperm characteristics and morphology as is normally established prior to cryopreservation ( $>70 \%$ normal sperm morphology and $>70 \%$ motility).

Four hundred eleven cows calved between September 2007 and January 2008. The time of pregnancy was calculated based on the dates of insemination and birth. The birth weight (BW) of the calves was measured using a mobile scale. The animals were divided into three lots: Lot 1 contained the 157 cows that calved in September and October and their calves (85 pure-bred Nellore and 72 cross-bred); Lot 2 contained the 97 cows that calved in November and December and their calves (28 purebred Nellore and 69 cross-bred); and Lot 3 contained the 157 cows that calved in January and their calves (9 pure-bred Nellore and 145 cross-bred).

Weaning occurred when the calves were 7 months old, at which time they were weighed using an electronic scale. We estimated calf weight at 205 days (P205) using the formula: $\mathrm{P} 205=\mathrm{BW}+205 \quad(\mathrm{WW}-\mathrm{BW}) / \mathrm{ID}$, where: $\mathrm{BW}=$ birth weight; $\mathrm{WW}=$ weaning weight and ID $=$ weaning age.

The body condition score (BCS) of the cows was determined at the time of calving and again at the time of weaning based on a scale devised by Radostits and Blood (1986), which ranges from 0 (extremely thin) to 5 (extremely fat), with a half-point gradation.

The breeding season began 10-15 days following calving, with a ratio of one bull to 25 cows, and lasted for 5 months. Subsequent calving began in September 2008 , and the date of birth and the sex of the calf were recorded.

The results were analysed using restricted maximum likelihood, using the SAS PROC MIXED procedure (Littell et al. 1996). The model for the weights analysis included the effects of the breed, the sex of the calf, the month of the birth and the interaction between two factors as fixed variables and the effects of the sire within the genetic group and the waste as random variables. We included the linear effect of the birth order along with the linear and quadratic effects of the BCS of each cow for the BW analysis, whereas the P205 analysis included the linear effect of the order of the partum.

In the analysis of the gestation period (GP), the model included the effects of the genetic group of the calf at first calving, the sex of the calf at first calving, the month of the first birth and the interactions between two factors, as well as the linear effect of the order of the partum as a covariate as fixed variables and the effects of the sire within the genetic group and the waste as random variables.
The model for the BCS analysis included the effects of the genetic group of the calf at first calving, the sex of the calf at first calving, the month of the first birth, the times of measurement and the interactions between two factors, as well as the linear effect of the birth order within the genetic group as a covariate as fixed variables and the effects of the sire within the genetic group, the cow within the breed of sire and the waste as random variables.

Was calculated the interval between the first and second partum for each cow that calved twice and classified the intervals in ascending order. Three hundred 24 days - the value of the shortest interval - was subtracted from each interval, so that the first delivery occurred on day zero and the days following parturition onset could be calculated. Statistical analysis was carried out using the SAS LIFETEST procedure (SAS 1996) to estimate the survival curves. The model included the effects of the month of calving, the sex and genetic group of the first calf, and the linear effect of parity as a covariate.

Total calving percentage was analysed via logistic regression, using the SAS LOGISTIC procedure (SAS 1996) procedure. The model included the effects of the first month of calving, the sex and genetic group of the first calf, the interaction between the sex of the first calf and the genetic group, and the linear and quadratic effects of the cow's BCS.

In all statistical analyses, the effect of the genetic group of the calf was assessed using two orthogonal contrasts: pure-bred vs cross-bred calves and $1 / 2$ Angus Red-1/2Nellore vs $1 / 2$ Simmental- $1 / 2$ Nellore calves. Comparisons between months of birth, when applicable, were made using Tukey's test. We adopted a 5\% significance level for all statistical evaluations.

To calculate the biological efficiency of different mating crosses in terms of $\mathrm{kg}$ of calf weaned/mating matrix, the estimated average of P205 was multiplied by the estimated rate of the second parturition for each genetic group.

\section{Results}

Neither the genetic group (Table 1) nor the sex of the calf had an effect on calf BW ( $p>0.05)$, but the month of birth did have an effect on BW (Table 2).

The P205 was $10 \%$ higher in cross-bred calves than in pure-bred Nellore calves (Table 3) and $5.15 \%$ higher $(p=0.0006)$ in male calves than in female calves (data

Table 1. Adjusted mean birth weight of calves in the three genetic groups

\begin{tabular}{lccc}
\hline Genetic group & Mean \pm SD $(\mathrm{kg})$ & Contrast & $\mathrm{p}$ \\
\hline Nellore & $29.09 \pm 0.38$ & Nellore vs cross-bred & 0.157 \\
$1 / 2$ Nellore-1/2Angus Red & $30.01 \pm 0.34$ & Crossbred vs cross-bred & 0.946 \\
$1 / 2$ Nellore-1/2Simmental & $29.96 \pm 0.59$ & & \\
\hline
\end{tabular}


Table 2. Adjusted mean birth weight and weaning weight of calves according to birth month

\begin{tabular}{lcc}
\hline Month of birth & Birth weight $(\mathrm{kg})$ & Weaning weight $(\mathrm{kg})$ \\
\hline September & $30.91 \pm 0.35^{\mathrm{ab}}$ & $187.76 \pm 2.71^{\mathrm{b}}$ \\
October & $29.13 \pm 0.78^{\mathrm{cb}}$ & $179.58 \pm 7.97^{\mathrm{b}}$ \\
November & $31.22 \pm 0.43^{\mathrm{ab}}$ & $186.35 \pm 3.36^{\mathrm{b}}$ \\
December & $29.34 \pm 0.73^{\mathrm{cb}}$ & $183.91 \pm 5.71^{\mathrm{b}}$ \\
January & $28.34 \pm 1.15^{\mathrm{c}}$ & $204.92 \pm 3.38^{\mathrm{a}}$ \\
\hline
\end{tabular}

${ }^{a, b, c}$ Means with no letters in common denote a significant difference (Tukey's test, $\mathrm{p}<0.05)$.

Table 3. Adjusted mean weight of calves estimated at 205 days of age, according to the genetic group

\begin{tabular}{lccc}
\hline Genetic group & Mean \pm SD $(\mathrm{kg})$ & Contrast & $\mathrm{p}$ \\
\hline Nellore & $176.82 \pm 3.24$ & Nellore vs cross-bred & 0.020 \\
$1 / 2$ Nellore-1/2Angus Red & $194.04 \pm 3.23$ & Crossbred vs cross-bred & 0.933 \\
$1 / 2$ Nellore-1/2Simmental & $194.64 \pm 5.84$ & & \\
\hline
\end{tabular}

Table 4. Adjusted mean of the gestation period of Nellore cows based on the genetic group of their calves

\begin{tabular}{lccc}
\hline Genetic group & $\begin{array}{c}\text { Mean } \pm \text { SD } \\
\text { (days) }\end{array}$ & Contrast & p \\
\hline Nellore & $293.70 \pm 0.55$ & $\begin{array}{c}\text { Nellore vs } \\
\text { cross-breds } \\
\text { Crossbreds vs } \\
\text { cross-breds }\end{array}$ & 0.0007 \\
$1 / 2$ Nellore-1/2Simmental & $285.35 \pm 0.52$ & 0.83 & \\
\hline
\end{tabular}

not shown). Calves born in January had a higher P205 (Table 2).

The GP of the dams of pure-bred Nellore calves was longer than that of the dams of both $1 / 2$ Angus Red-1/2 Nellore and $1 / 2$ Nellore- $1 / 2$ Simmental calves (Table 4).

There was no effect of the sex of the calf on the length of pregnancy (mean of 288.9 and 289.1 days for female and male calves, respectively).
The adjusted mean of the BCS at birth was 3.0, which decreased to a mean of $2.8(\mathrm{p}<0.0001)$ at the time of weaning. There was no effect of the genetic group $(p>0.005)$ nor an interaction between the genetic group and the time of measurement $(\mathrm{p}>0.005)$, but there was an effect of the month of birth $(\mathrm{p}=0.0323)$ and an interaction between the month of birth and age $(p<0.0001)$. As shown in Fig. 1, the BCS increased between time of birth and time of weaning both for cows that calved in September and weaned in April and for cows that calved in October and weaned in May. The BCS decreased, however, for cows that calved in the months of November, December and January and weaned in June, July and August, respectively (i.e. during the dry season).

The parturition curve analysis revealed that the mothers of pure-bred Nellore calves started calving earlier $(p=0.0027)$ than did the mothers of cross-bred calves (Fig. 2) and consequently became pregnant earlier in the first breeding season. The linear and quadratic effects $(p=0.0280)$ were also observed in parity cows, highlighting the greater degree of difficulty that primiparous and older cows (more than six parturitions) have in conceiving. No effect was observed on either the month of birth or the sex $(p>0.005)$ of calves in the shape of the curve.

The accumulated calving rate at 90 and 120 days was higher $(p=0.0118$ and $p=0.0320)$ in cows giving birth to pure-bred Nellore calves than in cows giving birth to cross-bred calves. For the final rate of calving at 150 days, no significant difference was observed $(p>0.005)$ between genetic groups (80.6, 76.4 and $76.2 \%$ for mothers of Nellore, $1 / 2$ Nellore- $1 / 2$ Angus Red and $1 / 2$ Nellore $-1 / 2$ Simmental, respectively).

\section{Discussion}

The results of the P205 analysis were similar to those of Barbosa and Alencar (1995) and Cubas et al. (2001), who reported a $10-12 \%$ higher average weight at weaning for cross-bred calves than for pure-bred Nellore calves. Vargas et al. (2013), in contrast, compared $1 / 2$ Simmental- $1 / 2$ Nellore calves with pure-bred Nellore
Fig. 1. Body condition score of Nellore cows according to calving and weaning months. Different values in the same month denote a significant difference $(F$-test, $\mathrm{p}<0.01)$

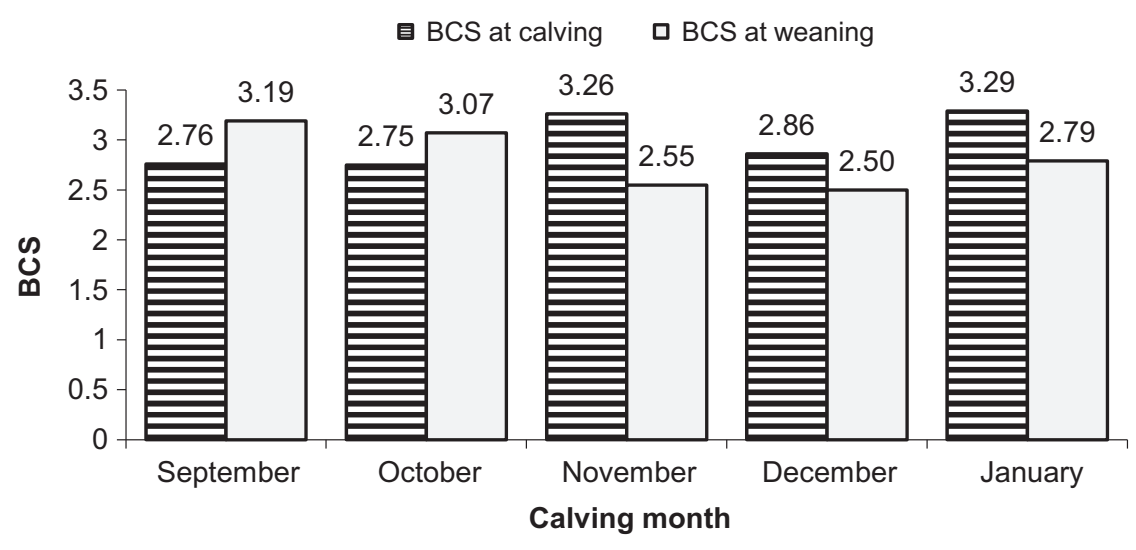




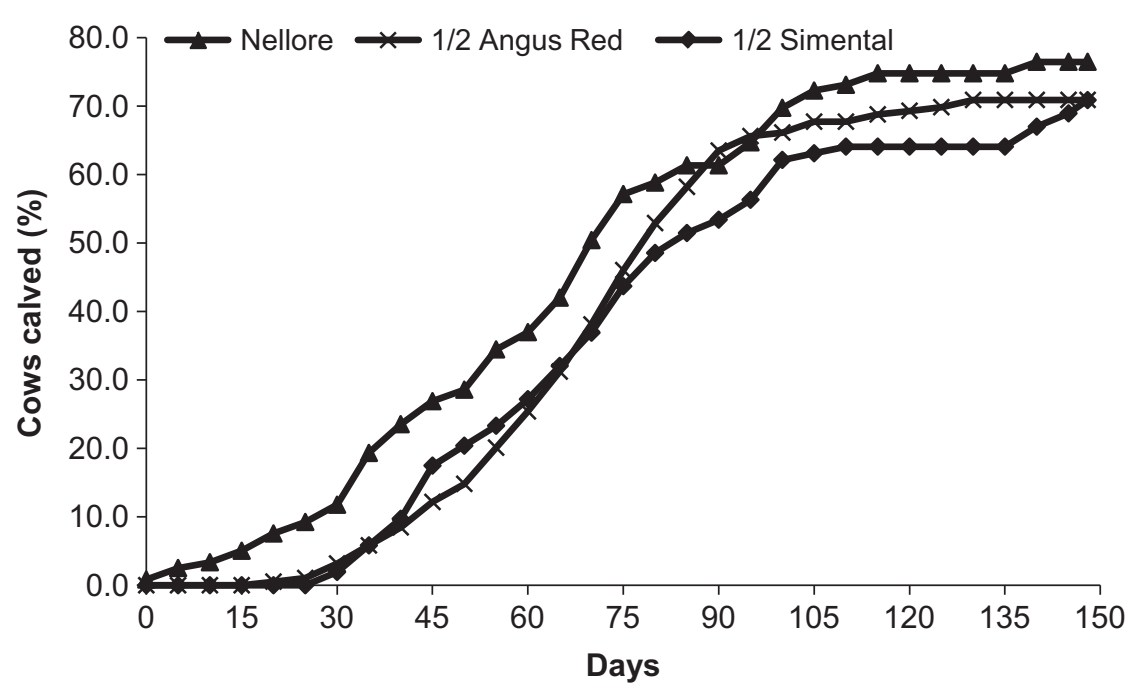

Fig. 2. Cumulative percentage of calving per total cows mated (unadjusted data) calves and found only a $6 \%$ difference in favour of the cross-bred calves.

The results of this study differ from those found in the literature, which predominantly suggest that calves born in the dry season tend to have a higher weaning weight than do calves born in the wet season (Alencar et al. 1999; Cubas et al. 2001; Bocchi et al. 2004; Bocchi and Albuquerque 2005). The climatic conditions in 2008 were, however, atypical for the region: the annual rainfall amounted to $1400 \mathrm{~mm}$ and was evenly distributed throughout the year, facilitating the growth of high-quality pasture until early August, when the last calves were weaned. The difference could account for the better forage that the animals born in January had in their paddocks.

The GP that we recorded was in accordance with that reported by Gunsky et al. (2001), who found that the average Nellore pregnancy period (PP) in Brazil is 295 days. Vargas et al. (2013) observed that the GP of Nellore mothers of pure-bred calves was 8 days longer than that of mothers of cross-bred calves, whereas Koger (1980) and Browning et al. (1996) observed shorter PPs for mothers of cross-bred calves. Baruselli et al. (2007) noted that the pregnancy of Bos taurus indicus is on average 10 days longer than that of B. taurus (292 vs 282 days, respectively). Such results suggest that there is an important genetic component influencing GP.

On average, the GP for male calves was 2 days longer than that for female calves. Cavalcante et al. (2001) reported a 3-day difference in GP in favour of male Nellore calves, whereas Rocha et al. (2005), working with Nellore cows and cross-bred $1 / 2$ Nellore- $1 / 2$ Hereford calves, found that the GP was, on average, 1.5 days longer for male calves than for female calves.

The results of our BCS analysis are similar to those observed by Speidel et al. (2007), who found that cows had a higher BCS at the time of birth than they did at the time of weaning. Grecellé et al. (2006), working with
$1 / 2$ Nellore- $1 / 2$ Hereford cows, described the variation of the BCS matrix according to the calving date and the relationship between the initial BCS (i.e. at parturition) and the rates of conception: the pregnancy rates can increase by as much as $11 \%$ with every increase of a half-point (0.5) in the BCS for cows with a BCS between 2.0 and 3.5 (on a scale of 1-5) at the time of calving.

In relation to reproductive efficiency, Doornbos et al. (1986) found a higher rate of pregnancy, weight gain and BCS in Hereford heifers that gave birth to Hereford calves than in Hereford mothers of $1 / 2$ Angus $-1 / 2$ Hereford or $1 / 2$ Simmental $-1 / 2$ Hereford calves. This difference was more evident in the mothers of $1 / 2$ Simmental- $1 / 2$ Hereford calves. The authors concluded that because cross-bred calves were generally larger, their higher nutritional demands compromised the reproductive performance of their mothers, which is partially in accordance with our work.

Browning et al. (1995), studying Brahman mothers of pure-bred Brahman, $1 / 2$ Angus- $-1 / 2$ Brahman and $1 / 2$ Tuli-1/2Brahman calves, reported a shorter average PP but longer between-birth intervals among the mothers of cross-bred calves, which we also noted. The authors attributed this difference to suckling, as the cross-bred calves were heavier at weaning and appeared to suckle more.

This study also revealed heavier cross-bred calves. However, because the breed of the calf had no effect on the mother's BCS and because there was no interaction between the genetic group and the time of BCS measurement, the genetic group of the calf did not seem to influence the energy balance of the mother. Vargas et al. (2013) reported that the milk consumption of cross-bred calves birthed by Nellore mothers was $0.42 \mathrm{~kg} / \mathrm{head} /$ day higher than that of pure-bred Nellore calves $(8.6 \%)$, but a body condition analysis of the mother cows suggested that the genetic group of the calf had an effect on the mother's health or performance. 
The higher WW of the cross-bred calves therefore appears to be mainly due to an extended grazing period (Rodrigues 2009).

The frequency, intensity and duration of suckling are primarily responsible for post-partum anoestros in cows that do not experience nutritional deficiencies. Intense suckling induces neurohormonal stimuli that are capable of reducing the release of GnRH and suppressing LH concentrations, which leads to the suppression of ovulation (Williams 1990). However, Rodrigues (2009) observed a higher frequency (3.74 vs 3.30 feedings/day) and a longer duration (7.39 vs $7.80 \mathrm{~min} /$ feeding) of feeding behaviour by purebred Nellore calves and no significant difference in the total duration of suckling. It is therefore not possible to attribute the best reproductive performance of mothers of pure-bred Nellore calves to feeding, as observed in the present work.

Browning et al. $(1995,1996)$ found that the concentrations of $17-\beta$ estradiol were higher in the mothers of cross-bred Angus-Brahman calves than they were in the mothers of purebred Brahman or Tuli-Brahman calves prior to partum; the progesterone concentrations did not differ between the genetic groups before and after partum, whereas prostaglandin F2a postpartum was higher in the mothers of Tuli-Brahman calves than in the mothers of purebred Brahman or Brahman-Angus calves. These results correlated with the longest period of anoestrus observed in the mothers of cross-bred calves, but the authors did not provide a clear explanation for the hormonal mechanism involved.

The interval between the onset of Breeding season (BS) and conception could be considered the key parameter for evaluating the reproductive efficiency of cattle on beef farms that use a defined BS. A higher probability of pregnancy during the initial phase of BS is correlated with better reproductive performance, a lower risk of culling, and higher profitability (Morton 2010; Sá Filho et al. 2013). Under the prevailing environmental and management conditions, the mothers of purebred calves demonstrated a higher reproductive efficiency over a 3-month breeding season, a time span that is normally recommended for Zebu cows. The production of weaned calves was $129.5 \mathrm{~kg} / \mathrm{cow}$ mated to purebred mothers and $111 \mathrm{~kg} /$ cow mated to cross-bred mothers, demonstrating that the purebred system is biologically more efficient than the cross-bred system. It required approximately 5 months of the breeding season for the cross-bred system to become more biologically efficient than the pure system (151.0 vs $137.6 \mathrm{~kg} / \mathrm{cow}$ mated, respectively). However, long breeding seasons have disadvantages, including the higher costs of employing skilled labour for a longer period of time, a lower uniformity of weaning weights, a lower average weight at the time of weaning, and potentially lower birth rates because calving will often occur at the end of the breeding season or stretch into unfavourable seasons.

For the cross-breeding system of calf production to attain the same degree of economic efficiency as the purebred system, $1 \mathrm{~kg}$ of weaned cross-bred calf would have to be worth $16.7 \%$ more than $1 \mathrm{~kg}$ of weaned purebred calf, allowing for a breeding season of 90 days and identical rates of calf mortality in both systems. Other alternatives for achieving the same results reproductive efficiency would be changes in management in mothers of cross-bred calves as early weaning, or postpartum supplementation. But in this case an economic evaluation should be highlighted.

\section{Conclusion}

Cross-bred calves, on average, were $10 \%$ heavier at the time of weaning than were pure-bred calves. Mating Nellore females with Simmental or Angus Red bulls delayed their reconception.

The calving rate of the Nellore mothers giving birth to cross-bred calves was lower than that of the Nellore mothers giving birth to pure-bred calves in a 3-month breeding season under the prevailing experimental conditions. The calving rate of the mothers of crossbred calves is only comparable to that of the mothers of purebred calves approximately 5 months into the breeding season.

Finally, in terms of $\mathrm{kg}$ of calf weaned/mated cow over a 3-month breeding season, the production of pure-bred calves was the more biologically efficient management system for the herd.

\section{Conflict of interest}

None of the authors have any conflict of interest to declare.

\section{Author contributions}

The authors Rodrigues and Wechsler were primarily responsible for experimental design, and Dr Rodrigues also responsible for data collection, along with Dr Nogueira. Regarding data analysis, this was the responsibility of Dr. Wechsler, and final draft the paper was performed by three authors together.

\section{References}

Alencar MM, Tulio RR, Corrêa LA, 1999: Pesos e relações de peso de bezerros filhos de vacas Nelore e cruzadas Canchim $\mathrm{x}$ Nellore. Rev Bras Zootec 28, 968-973.

Barbosa PF, Alencar MM, 1995: Sistema de cruzamentos em bovinos de corte: estado da arte e necessidades de pesquisa. In: Proceedings of Meeting of the Sociedade Brasileira de Zootecnia 32, Brasilia.

Baruselli PS, Gimenes LU, Sales JN, 2007: Fisiologia reprodutiva de fêmeas taurinas e zebuínas. Rev Bras Reprod Anim 31, 205-211.
Bocchi AL, Albuquerque LG, 2005: Efeitos da idade da vaca e da data Juliana de nascimento sobre o ganho médio diário de bezerros de corte no período prédesmame. Arquivo Brasileiro de Medicina Veterinária e Zootecnia 58, 524-532.

Bocchi AL, Teixeira RA, Albuquerque LG, 2004: Idade da vaca e mês de nascimento 
sobre o peso ao desmame de bezerros Nelore nas diferentes regiões brasileiras. Acta Scient Anim Sci 26, 475-482.

Browning R Jr, Leite-Browning ML, Neuendorf DA, et al., 1995: Preweaning growth of Angus (Bos Taurus), Brahman (Bos indicus) and Tuli (Sanga) sired calves and reproductive performance of their Brahman dams. J Anim Sci 73, 25582563.

Browning R Jr, Leite-Browning ML, Lewis AW, Randel RD, 1996: Sire breed of calf influences peripartum endocrine profiles and postpartum anestrus im Brahman cows. Domest Anim Endocrinol 13, 511517.

Cavalcante FA, Martins Filho RM, Campello CC, Lobo RNB, Martins CA, 2001: Período de gestação em rebanho Nellore na Amazônia oriental. Rev Bras Zootec 30, 1451-1455.

Cubas AC, Perotto D, Abrahão JS, Mella SC, 2001: Desempenho até a desmama dos bezerros Nellore e cruzas com Nellore. Rev Bras Zootec 30, 694-701.

Doornbos DE, Steffan CA, Kress D, Anderson D, 1986: Postweaning growth and early reproductive traits of different biological types of heifers. Montana Ag Res 3, 5-6.

Euclides Filho K, Figueiredo GR, Euclides VPB, 2003: Desempenho de diferentes grupos genéticos de bovinos de corte em confinamento. Rev Bras Zootec 32, 1114 1122.

Flores R, Looper ML, Rorie RW, Lamb MA, Reiter ST, 2007: Influence of body condition and bovine somatrotopin on estrous behavior reproductive performance, and concentrations of serum somatrotopin and plasma fatty acids in postpartum Brahman-influenced cows. J Anim Sci 85, 1318-1329.

Grecellé RA, Barcellos JOJ, Bracini Neto J, Costa EC, Prates ER, 2006: Taxa de prenhez de vacas Nellore X Hereford em ambiente subtropical sob restrição alimentar. Rev Bras Zootec 35, 1423 1430 .

Gunsky RR, Garnero AD, Bezerra LAF, Corrado MP, Lobo RB, 2001: Idade ao primeiro parto, período de gestação e peso ao nascimento em vacas Nellore. Rev Ciência Agron 32, 45-52.

Koger M, 1980: Effective crossbreeding systems utilizing zebu cattle. J Anim Sci 50, 1215-1220.

Littell RC, Milliken GA, Stroup WW, et al., 1996: SAS ${ }^{\circledR}$ System for Mixed Models. SAS Institute Inc., Cary, NC, 633 p.

Montiel F, Ahuja C, 2005: Body condition and suckling as factors influencing the duration of postpartum anestrus in cattle: a review. Anim Reprod Sci 85, 1-26.

Morton JM, 2010: Interrelationships between herd-level reproductive performance measures based on intervals from initiation of the breeding program in yearround and seasonal calving dairy herds. J Dairy Sci 93, 901-910.

Paschal JC, Sanders JO, Kerr JL, 1991: Calving and weaning characteristics of Angus-, Gray Brahman-, Gir-, Indubrazil-, Nellore- and Red Brahman-sired F1 calves. J Anim Sci 69, 2395-2402.

Radostits OM, Blood DC, 1986: Manual de controle da saúde e produção dos animais. Ed. Manole, São Paulo, 530 p.

Rocha JCMC, Tonhati H, Alencar MM, Lôbo RB, 2005: Componente de variância para o período de gestação em bovinos de corte. Arquivo Brasileiro de Medicina Veterinária e Zootecnia 57, 784-791.

Rodrigues WB, 2009: Desempenho e comportamento de vacas Nelore e suas crias puras ou mestiças no Brasil Central. Tese de Doutorado. Depto. Produção Animal, Faculdade de Medicina Veterinária e Zootecnia, UNESP-BOTUCATU, 70 p.

Sá Filho MF, Penteado L, Reis EL, Reis TANPS, Galvão K, Baruselli PS, 2013: Timed artificial insemination early in the breeding season improves the reproductive performance of suckled beef cows. Theriogenology 79, 625-632.

S.A.S. Statistic Analysis System, 1996: User's Guide. Version 6.12. S.A.S. Institute Inc., Cary, NC, USA.

Short RE, Bellows RA, Staigmiller RB, 1990: Physiological mechanisms controlling anestrous and infertility in postpartum beef cattle. J Anim Sci 68, 799-816.

Speidel SE, Enns RM, Garrick DJ, 2007: Weaning weight inheritance in environments classified by maternal body weight change. J Anim Sci 85, 610-617.

Teixeira RA, Albuquerque LG, 2003: Efeitos ambientais que afetam o ganho de peso pré-desmama em animais Angus $\mathrm{x}$ Nellore e Hereford x Nellore. Rev Bras Zootec 32, 887-890.

Vargas FM Jr, Wechsler FS, Oliveira MVM, Rossi P, Seno LO, Fernandes ARM, Camilo FR, 2013: Reproductive efficiency of Nellore cows nursing Nellore or crossbred Simmental $\times$ Nellore calves. Rev Bras Zootec 42, 475-480.

Williams GL, 1990: Suckling as a regulator of postpartum rebreeding in cattle: a review. J Anim Sci 68, 831-852.

Wiltbank JN, Rowden WW, Ingalls JE, et al., 1962: Effect of energy level on reproductive phenomena of mature Hereford cows. J Anim Sci 21, 219-225.

Submitted: 22 Oct 2014; Accepted: 13 Feb 2015

Author's address (for correspondence): Ériklis Nogueira, Brazilian Agricultural Research Corporation, EMBRAPA Pantanal, Rua 21 de Setembro, 1880, Bairro Nossa Senhora de Fátima, Corumbá 79320-900, MS, Brazil.

E-mail: eriklis.nogueira@embrapa.br 